\title{
Glutathione S-transferase M1 (GSTM1) polymorphism in two Brazilian populations
}

\author{
Ana Hatagima ${ }^{I}$, Maria Nazaré Klautau-Guimarães ${ }^{2}$, Felizardo Penalva da Silva ${ }^{2}$ and Pedro Hernan Cabello ${ }^{1}$
}

\begin{abstract}
The distribution of GSTM1 phenotype frequencies was studied in two Brazilian samples composed of healthy and unrelated blood donors of both sexes ranging in age from 18 to 61 years. The first sample consisted of 658 individuals from Rio de Janeiro, and the second included 179 individuals from Brasília. The GSTM1 phenotypes were detected using PCR reactions and subsequent digestion by the restriction enzyme HaeII. The GSTM1 null phenotype frequency was $46 \%$ and $49 \%$ for Rio de Janeiro and Brasília samples, respectively. The GSTM1 phenotype distributions were not in agreement with Hardy-Weinberg equilibrium in either sample, $\chi^{2}=11.49(\mathrm{P}<0.001)$ for Rio de Janeiro and $\chi_{1}^{2}=6.77(\mathrm{P}<0.01)$ for Brasília. This deviation from Hardy-Weinberg equilibrium may be due to factors such as selection, errors in the phenotype determination or incomplete panmixia of the Brazilian population, whose main racial components are Caucasians, Africans and Indians.
\end{abstract}

\section{INTRODUCTION}

The glutathione S-transferase (GST) enzyme system constitutes a family of multifunctional enzymes which play an important role in biotransformation and detoxification of many different xenobiotic and endogenous substances (Wolkoff, 1980; Mannervick, 1985). GSTM1, a mu class gene of the GST family is polymorphic and has three alleles: two of them are active, GSTM $1 *$ A and GSTM $1 * \mathrm{~B}$, and the third, GSTM $1 * 0$, is a null allele. The GSTM $1 * 0$ allele is a deletion and homozygotes for this allele (null phenotype) do not produce any protein product. The GSTM1*A and GSTM1*B alleles code for the GSTM1 A and GSTM1 B proteins (Seidegard et al., 1988). These proteins are functionally identical (Widersten et al., 1991) and differ only in a single amino acid. The GSTM1 A protein contains lysine at position number 172 (DeJong et al., 1988), whereas the GSTM1 B protein contains asparagine at this position (Seidegard et al., 1988). The products from these two genes combine with each other to form homo- and hetero-dimeric active enzymes (Seidegard et al., 1988; DeJong et al., 1991).

This locus is interesting because of its polymorphic characteristics and the high frequency of the null phenotype (40-60\%) in most of the populations studied, which varies among ethnic groups (Board, 1981; Harada et al., 1987; Groppi et al., 1991; Mikelsaar et al., 1994). Reports of a lower incidence of the null allele in Nigerians and Indians contrast with a higher incidence in Chinese and some Micronesians (Board et al., 1990; Zhao et al., 1994; Lin et al., 1994). There are also differences in the other alleles: the frequency of GSTM $1 * A$ is higher and that of GSTM $1 * \mathrm{~B}$ is lower in Indians, French, English and Nigerians than in Chi- nese and Japanese populations (Laisney et al., 1984; Harada et al., 1987; Board et al., 1990; Zhao et al., 1994; Heagerty et al., 1996). In addition, homozygosity for GSTM $1 * 0$ is associated with an increased risk of several pathologies, including some malignancies (Strange, 1993; Baranov et al., 1996; Helzlsouer et al., 1998). Thus, GSTM1 polymorphism could be used, possibly in combination with other detoxifying enzyme polymorphisms, to identify high-risk individuals in clinical surveillance programms (Strange, 1993). This is complicated, however, by the substantial differences in the GSTM1 allele frequencies observed in different ethnic groups. These frequencies are known in many populations but there are limited data from Brazilian populations.

In this work our aim was to study GSTM1 gene polymorphism in the Brazilian population, since it is a special case of a tri-racial mixture of Caucasian, African, and Indian genes (Krieger et al., 1965).

\section{MATERIAL AND METHODS}

Blood samples from unrelated adult volunteers of both sexes, with ages ranging from 18 to 61 years were collected from the Clementino Fraga Filho Hospital Blood Bank (Rio de Janeiro) and from the Brasília Blood Bank. The Rio de Janeiro sample consisted of 658 subjects (392 males and 266 females) and the Brasília sample was comprised of 179 subjects (154 males and 25 females). DNA was extracted from $5 \mathrm{ml}$ of venous blood collected in EDTA Vacutainer tubes and stored at $4^{\circ} \mathrm{C}$ (Lahiri and Nurnberger Jr., 1991).

The GSTM1 polymorphisms were identified by the use of site-directed mutagenesis of allele-specific PCR primers. All PCR reactions were performed using three primers

\footnotetext{
${ }^{l}$ Departamento de Genética, Instituto Oswaldo Cruz, Pavilhão Leônidas Deane, Av. Brasil, 4365, 21045-900 Rio de Janeiro, RJ, Brasil. Send correspondence to A.H. Fax: +55-21-260-4282. E-mail: hatagima@gene.dbbm.fiocruz.br ${ }^{2}$ Departamento de Genética e Morfologia, Universidade de Brasília, DF, Brasil.
} 
to GSTM1. These comprised, firstly, a common GSTM1specific primer to intron 6 (GSTM1I6) and secondly, primers to exon 7, one specific to GSTM1*A (GSTM1E7A) and another (GSTM17B) specific to GSTM1*B. In pilot studies using DNA from subjects with known GSTM1 A or GSTM1 B phenotypes GSTM1E7A did not anneal to GSTM1*B and vice-versa (Fryer et al., 1993). The finding of a 268-bp DNA fragment ( $\beta$-globin) confirmed the success of amplification (Saiki et al., 1988). Negative controls were included in every run to test possible contamination.

Ten microliters of the PCR product was analyzed on $2 \%$ agarose gels stained with ethidium bromide. At this stage two groups of individuals were determined: one with positive GSTM1 alleles (GSTM1+) and another without them (GSTM1-). This amplified material was subsequently digested by HaeII for $4 \mathrm{~h}$ at $37^{\circ} \mathrm{C}$, to differentiate GSTM1*A and GSTM1*B because the GSTM1*A primer differs from the GSTM ${ }^{*}$ A sequence by an $A \rightarrow$ G substitution at the 3' end of the primer, thus introducing a HaeII restriction site into the amplified DNA. DNA from subjects with positive GSTM1 alleles allowed amplification of a 132-bp fragment. However, while GSTM1E7A and GSTM17B effected amplification of a fragment of the same size from GSTM $1 * A$ and GSTM $1 *$ B, respectively, the sequence of the PCR product differed by two bases, introducing a HaeII restriction site into the amplified DNA. Digestion by HaeII produced 112- and 20-bp fragments (corresponding to GSTM1 A). DNA fragments were resolved by electrophoresis in $4 \%$ agarose gels, which were ethidium bromide stained and photographed under UV light.

\section{RESULTS AND DISCUSSION}

It is apparent from the GSTM1 phenotype distribution (Table I) that gene frequencies of the two samples are very similar. The GSTM1 null phenotype frequencies were 46 and 49\%, for Rio de Janeiro and Brasília, respectively. These values are similar to the data found in the literature for most human populations (Table II).

Both samples were also tested in order to check if there were differences in the GSTM1 phenotype frequencies according to age, sex or ethnic group (White versus Black), but no significant differences were observed. A tendency towards a decline in GSTM $1 * 0$ frequencies for the Black group in Brasília and Rio de Janeiro samples was observed, but it is not statistically significant (Tables III and IV).

The difference in the GSTM $1 * 0$ frequencies observed among races in the Rio de Janeiro and Brasília samples was not significant, however, it was borderline in the Rio de Janeiro sample, in which allelic frequencies were $42 \%$ in the Black group and $49 \%$ in the White group $(\mathrm{P}=0.06)$. Previous studies have shown that the admixture proportion in Rio de Janeiro is $40.18 \%$ Caucasian, $52.06 \%$ Black, and 0.08\% Native (Lopez-Camelo et al., 1996). This preponderance of black genes could be responsible for the GSTM $1 * 0$ frequency (46\%) in the Rio de Janeiro sample which is slightly lower than Brasília (49\%). The racial admixture proportion of the Brasília population is unknown, but the proportion of black genes is certainly lower than in the Rio de Janeiro population, based on historical data. This is probably due to the recent founding of the Brasília population by migrants from many regions of the country, mainly from the Northeast, which is a tri-racial mixture with gene proportions of Caucasian $=0.586$, Black $=0.301$, and Indian $=0.113$ (Krieger et al., 1965).

Studies of African samples have shown that the frequency of the GSTM1 null phenotype is lower (22-38\%) than in other populations (Bell et al., 1993; Lin et al., 1994; Zhao et al., 1994; Mukanganyama et al., 1997; Arruda et

Table I - Test for Hardy-Weinberg equilibrium of two Brazilian populations (Rio de Janeiro and Brasília).

\begin{tabular}{|c|c|c|c|c|c|c|}
\hline \multirow[t]{3}{*}{ Phenotype } & \multicolumn{3}{|c|}{ Rio de Janeiro } & \multicolumn{3}{|c|}{ Brasília } \\
\hline & \multicolumn{2}{|c|}{ No. of individuals } & \multirow[t]{2}{*}{$\chi^{2}$} & \multicolumn{2}{|c|}{ No. of individuals } & \multirow[t]{2}{*}{$\chi^{2}$} \\
\hline & Obs. & Exp. & & Obs. & Exp. & \\
\hline GSTM1 0 & 305 & 291.73 & 0.603 & 87 & 81.63 & 0.354 \\
\hline GSTM1 A & 197 & 211.58 & 1.004 & 43 & 48.96 & 0.726 \\
\hline GSTM1 B & 105 & 120.24 & 1.932 & 33 & 39.07 & 0.944 \\
\hline GSTM1 AB & 51 & 34.45 & 7.951 & 16 & 9.34 & 4.749 \\
\hline Total & 658 & 658.00 & 11.491 & 179 & 179.00 & 6.773 \\
\hline P-value & \multicolumn{3}{|c|}{$<0.001$ (1 d.f.) } & P-value & \multicolumn{2}{|c|}{$<0.01$ (1 d.f.) } \\
\hline Alleles & & & SE & Alleles & Frequencies & $\mathrm{SE}$ \\
\hline GSTM1*A & & & 0.0120 & GSTM1*A & 0.1788 & 0.0217 \\
\hline GSTM1*B & & & 0.0095 & GSTM1*B & 0.1459 & 0.0198 \\
\hline GSTM1*O & & & 0.0131 & GSTM1*O & 0.6753 & 0.0242 \\
\hline
\end{tabular}

Obs. - Observed; Exp. - expected; SE - standard error of the mean. 
al., 1998). These results corroborate our finding of a lower frequency of this allele in our Black group.

The distribution of the GSTM1 null phenotype varies in the different ethnic groups (Table II). Despite the fact that the methods to determine GSTM1 phenotypes were different (electrophoresis in starch gel or S-GEF and PCR) the results were similar. Most of these populations are in Hardy-Weinberg equilibrium, except for the Brazilian samples $\left(\chi^{2}{ }_{1}=11.49 ; \mathrm{P}<0.001\right.$ and $\chi^{2}{ }_{1}=6.77 ; \mathrm{P}<0.01$, for Rio de Janeiro and Brasília, respectively). This departure from Hardy-Weinberg equilibrium had already been observed in a previous study of a sample from the city of Ribeirão Preto (Klautau-Guimarães et al., 1993). In the three Brazilian samples the deviation of the equilibrium proportions is mainly due to an excess of GSTM1 A/B heterozygotes.

Three factors might explain the deviation from HardyWeinberg equilibrium proportions. Firstly racial mixture, because GSTM1 frequency varies in the different ethnic groups and our samples are basically tri-hybrids. Brazilian populations are a product of admixture (Krieger et al., 1965) among Caucasian (mainly Portuguese), Black (Bantu and Sudanese origin) and native Indians. We did not find significant differences among the ethnic groups, although the results were borderline. This could be explained by the fact that our race classifications were relatively subjective.

Table II - Distribution of glutathione S-transferase M1 phenotype frequencies in different populations.

\begin{tabular}{|lrrrrrl|}
\hline \multirow{2}{*}{ Samples } & \multicolumn{4}{c}{ Phenotype GSTM1 } & \multirow{2}{*}{$\chi^{2}$ (d.f.=1) } & Methods \\
\cline { 2 - 5 } & $\mathrm{A}$ & $\mathrm{B}$ & $\mathrm{A} / \mathrm{B}$ & 0 (Null) & & \\
\hline Brazilian (RJ) $^{\mathrm{a}}$ & 197 & 105 & 51 & $305(46.0 \%)$ & 11.49 & PCR \\
Brazilian (DF) $^{\mathrm{a}}$ & 43 & 33 & 16 & $87(48.6 \%)$ & 6.77 & PCR \\
Brazilian (SP) $^{\mathrm{b}}$ & 21 & 10 & 7 & $35(47.9 \%)$ & 3.98 & S-GEF \\
Nigerians $^{\mathrm{c}}$ & 49 & 4 & 1 & $15(21.7 \%)$ & 0.09 & PCR \\
Japanese $^{\mathrm{d}}$ & 13 & 68 & 5 & $80(48.2 \%)$ & 0.04 & S-GEF \\
Chinese $^{\mathrm{e}}$ & 10 & 28 & 2 & $56(58.3 \%)$ & 0.01 & S-GEF \\
Indians $^{\mathrm{e}}$ & 15 & 7 & 6 & $15(35.0 \%)$ & 1.93 & S-GEF \\
French $^{\mathrm{f}}$ & 24 & 5 & 3 & $24(42.9 \%)$ & 0.31 & S-GEF \\
English $^{\mathrm{g}}$ & 158 & 74 & 23 & $306(54.5 \%)$ & 1.96 & PCR \\
\hline
\end{tabular}

d.f. $=$ Degrees of freedom. S-GEF $=$ Starch gel electrophoresis and PCR $=$ polymerase chain reaction. ${ }^{\text {aPresent paper. }{ }^{b} \mathrm{Klautau}-G u i m a r a ̃ e s, 1993 .}$ 'Zhao et al., 1994. ${ }^{\mathrm{d}}$ Harada et al., 1987. ${ }^{\mathrm{e} B o a r d}$ et al., 1990. ${ }^{\mathrm{f}}$ Laisney et al., 1984. ${ }^{\text {TH}}$ Heagerty et al., 1996.
Secondly, the association of GSTM1 polymorphism with many types of diseases is documented by several studies, which indicate that individuals homozygous for the GSTM1*0 allele seem to have a higher risk for some types of lung cancer (Seidegard et al., 1986), stomach cancer (Harada et al., 1992), bladder cancer (Abdel-Rahman et al., 1998), cystic fibrosis (Baranov et al., 1996) and atherosclerosis (Pessah-Rasmussen et al., 1992). The higher frequencies of the GSTM $1 * 0$ allele, in spite of its association with some diseases, could be explained by the fact that most of these diseases are manifested at a mature age when most GSTM1 0/0 homozygous individuals have already transmitted the GSTM $1 * 0$ gene to their descendents (Board et al., 1990). It has also been observed that in individuals with gastrointestinal, brain and skin cancer the GSTM1 A/ B genotype is less common than in controls (Strange et al., 1991; Strange, 1993; Heagerty et al., 1994), suggesting that this polymorphism is going through some kind of selection that is favorable to the GSTM1 A/B heterozygous and/or disadvantageous to GSTM1 0/0 homozygous individuals. When we consider that GSTM1 0/0 homozygous individuals are deficient in GST, a carcinogen detoxification enzyme, it is reasonable to suggest that these individuals have higher risks when exposed to carcinogens. GSTM1 A/B heterozygous individuals, in turn, express both alleles and have higher enzyme activity (Brockmöller et al., 1992, 1994), and are consequently better protected and more effective in the process of detoxification. In the specific case of GSTM1, since the null allele frequency is high, the Hardy-Weinberg model predicts that most of the GSTM1 A and GSTM1 B phenotypes are heterozygous for GSTM $1 * 0$. These two phenotypes have a lower average activity than that of GSTM1 A/B heterozygous individuals. This selection, which is favorable to GSTM1 A/B heterozygotes and/or unfavorable to GSTM1 0/0 homozygotes, could have taken place recently because of increased industrialization and the exposure to toxic substances, such as insecticides, cigarettes and other chemical pollutants and carcinogens. In our study the observed frequency of GSTM1 A/B heterozygotes is higher than the expected frequency and is the main reason for the departure of our data from Hardy-Weinberg equilibrium.

Thirdly, there may be an error in the determination of the GSTM1 phenotypes. We can not differentiate GSTM1 A/A from GSTM1 A/0 individuals, so we consider all of

Table III - Distribution of glutathione S-transferase M1 allele frequencies in racial sub-groups of the Brasília sample.

\begin{tabular}{|lccccc|}
\hline Alleles & \multicolumn{5}{c|}{ Allele frequencies } \\
\cline { 2 - 5 } & White $(\mathrm{N}=53)$ & $\begin{array}{c}\text { Light } \\
\text { Mulatto }(\mathrm{N}=54)\end{array}$ & $\begin{array}{c}\text { Medium } \\
\text { Mulatto }(\mathrm{N}=51)\end{array}$ & $\begin{array}{c}\text { Dark } \\
\text { Mulatto (N =9) }\end{array}$ & Black (N=5) \\
\cline { 2 - 6 } & $0.174 \pm 0.039$ & $0.193 \pm 0.040$ & $0.180 \pm 0.039$ & $0.155 \pm 0.098$ & $0.216 \pm 0.150$ \\
$\mathrm{~B}$ & $0.141 \pm 0.035$ & $0.127 \pm 0.033$ & $0.149 \pm 0.036$ & $0.214 \pm 0.113$ & $0.216 \pm 0.150$ \\
O & $0.685 \pm 0.045$ & $0.680 \pm 0.045$ & $0.670 \pm 0.042$ & $0.630 \pm 0.093$ & $0.570 \pm 0.143$ \\
\hline
\end{tabular}


Table IV - Distribution of glutathione S-transferase M1 allele frequencies in racial sub-groups of the Rio de Janeiro sample.

\begin{tabular}{|cccc|}
\hline Allele & \multicolumn{3}{c|}{ Allele frequencies } \\
\cline { 2 - 4 } & White $(\mathrm{N}=429)$ & Mulatto $(\mathrm{N}=134)$ & Black $(\mathrm{N}=95)$ \\
\hline A & $0.186 \pm 0.014$ & $0.212 \pm 0.027$ & $0.313 \pm 0.038$ \\
B & $0.130 \pm 0.012$ & $0.110 \pm 0.020$ & $0.127 \pm 0.025$ \\
O & $0.684 \pm 0.016$ & $0.678 \pm 0.029$ & $0.560 \pm 0.037$ \\
\hline
\end{tabular}

them as class GSTM1 A. The same is true for the GSTM1 B phenotype. GSTM1 A/0 and GSTM1 B/0 heterozygous genotypes could give a weaker reaction in the electrophoresis gel, which would increase the probability of these individuals being considered as null homozygotes and consequently would overestimate the proportion of this phenotype and decrease the frequency of the GSTM1 A and GSTM1 $B$ phenotypes. On the other hand, our results do not show a significant difference in the expected values of these classes. A recent study (Arruda et al., 1998) on three distinct ethnic groups of Brazilians indicated GSTM1 null phenotype frequencies of $55 \%$ in Caucasian, $33 \%$ in descendants of Africans and $20 \%$ in Indian lineages. Taking into account the racial admixture in our samples our results are in agreement with those found by Arruda et al. (1998). The deviation from Hardy-Weinberg equilibrium verified in our study could be explained by selection, incomplete panmixia of these populations or other unknown factors.

\section{ACKNOWLEDGMENTS}

We thank Dr. Marcos Palatinik, C. Nogueira and all donors of Clementino Fraga Filho Hospital Blood Bank (Rio de Janeiro) for the generous gift of blood samples, and T.H. Teixeira and C.F. Marques for the English revision. This study was financed by the Fundação Oswaldo Cruz (FIOCRUZ) and Fundação de Amparo à Pesquisa do Rio de Janeiro (FAPERJ).

\section{RESUMO}

A distribuição das frequiências fenotípicas do gene GSTM1 de duas amostras brasileiras, compostas de doadores sanguíneos de ambos os sexos com idade entre 18 e 61 anos, foi estudada. A primeira amostra é composta de 658 indivíduos provenientes do Rio de Janeiro e a segunda de 179 indivíduos de Brasília. Os fenótipos da GSTM1 foram determinados utilizando-se a técnica da reação em cadeia da polimerase e subsequente digestão com a enzima de restrição HaeII. As freqüências observadas para o fenótipo GSTM1 nulo foram de 46,4\% e 48,6\% para as amostras do Rio de Janeiro e Brasília, respectivamente. Os resultados também mostram que a distribuição fenotípica da GSTM1 não está em equilíbrio de Hardy-Weinberg para ambas as amostras: $\chi^{2}{ }_{1}=$ $11,49(\mathrm{P}<0,001)$ para o Rio de Janeiro e $\chi^{2}{ }_{1}=6,77(\mathrm{P}<0,01)$ para Brasília. Este desequilíbrio pode ser atribuído a fatores como seleção, erros na determinação fenotípica ou panmixia ainda incompleta da população brasileira, cujos componentes raciais são caucasóides, africanos e índios.

\section{REFERENCES}

Abdel-Rahman, S.Z., Anwar, W.A., Abdel-AaL, W.E., Mostafa, H.M. and Au, W.W. (1998). GSTM1 and GSTT1 genes are potential risk modifiers for bladder cancer. Cancer Detect. Prev. 22: 129-138.

Arruda, V.R., Grignolli, C.E., Gonçalves, M.S., Soares, M.C., Menezes, R., Saad, S.T.O. and Costa, F.F. (1998). Prevalence of homozygosity for the deleted alleles of glutathione S-transferase mu (GSTM1) among distinct ethnic groups from Brazil: relevance to environmental carcinogenesis? Clin. Genet. 54: 210-214.

Baranov, V.S., Ivaschenko, T., Bakay, B., Aseev, M., Belotserkovskaya, R., Baranova, H., Malet, P., Perriot, J., Mouraire, P., Baskakov, V.N., Savitskyi, G.A., Gorbushin, S., Deyneka, S.I., Michnin, E., Barchuck, A., Vakharlovsky, V., Pavlov, G., Shilko, V.I., Guembitzkaya, T. and Kovaleva, L. (1996). Proportion of the GSTM1 0/0 genotype in some Slavic populations and its correlation with cystic fibrosis and some multifactorial diseases. Hum. Genet. 97: 516-520.

Bell, D.A., Taylor, J.A., Paulson, D.F., Robertson, C.N., Mohler, J.L. and Lucier, G.W. (1993). Genetic risk and carcinogen exposure: a common inherited defect of the carcinogen-metabolism gene glutathione $\mathrm{S}$ transferase M1 (GSTM1) that increases susceptibility to bladder cancer. J. Natl. Cancer Inst. 85: 1159-1164.

Board, P.G. (1981). Biochemical genetics of glutathione S-transferase in man. Am. J. Hum. Genet. 33: 36-43.

Board, P.G., Coggan, M., Johnston, P., Ross, V., Suzuki, T. and Webb, G. (1990). Genetic heterogeneity of the human glutathione transferases: a complex of gene families. Pharmacol. Ther. 48: 357-369.

Brockmöller, J., Gross, D., Kerb, R., Drakoulis, N. and Roots, I. (1992). Correlation between trans-stilbene oxide-glutathione conjugation activity and the deletion mutation in the glutathione S-transferase class Mu gene detected by polymerase chain reaction. Biochem. Pharmacol. 43: 647-650.

Brockmöller, J., Kerb, R., Drakoulis, N., Staffeldt, B. and Roots, I. (1994). Glutathione S-transferase M1 and its variants A and B as host factors of bladder cancer susceptibility: a case-control study. Cancer Res. 54:4103-4111.

DeJong, J.L., Chang, C.M., Whang-Peng, J., Knutsen, T. and Tu, C.P.D. (1988). The human liver glutathione S-transferase gene superfamily: expression and chromosome mapping of $\mathrm{Hb}$ subunit cDNA. Nucleic Acids Res. 16: 8541-8554.

DeJong, J.L., Mohandas, T. and Tu, C.P.D. (1991). The human Hb (Mu) class glutathione $\mathrm{S}$-transferases are encoded by a dispersed gene family. Biochem. Biophys. Res. Commun. 180: 15-22.

Fryer, A.A., Zhao, L., Alldersea, J., Pearson, W.R. and Strange, R.C. (1993). Use of site-directed mutagenesis of allele-specific PCR primers to identify the GSTM1 A, GSTM1 B, GSTM1 AB and GSTM1 null polymorphisms at the glutathione S-transferase, GSTM1 locus. Biochem. J. 295: 313-315.

Groppi, A., Coutelle, C., Fleury, B., Iron, A., Begueret, J. and Couzigou, P. (1991). Glutathione S-transferase class $\mu$ in French alcoholic cirrhotic patients. Hum. Genet. 87: 628-630.

Harada, S., Abei, M., Tanaka, N., Agarwat, D.P. and Goedde, H.W. (1987). Liver glutathione S-transferase polymorphism in Japanese and its pharmacogenetic importance. Hum. Genet. 75: 322-325.

Harada, S., Misawa, S., Nakamura, T., Tanaka, N., Ueno, E. and Nozoe, M. (1992). Detection of GST1 gene deletion by the polymerase chain reaction and its possible correlation with stomach cancer in Japanese. Hum Genet. 90: 62-64.

Heagerty, A.H.M., Fitzgerald, D., Smith, A., Bowers, B., Jones, P., Fryer, A.A., Zhao, L., Alldersea, J. and Strange, R.C. (1994). Glutathione Stransferase GSTM1 phenotypes and protection against cutaneous tumours. Lancet 343: 266-268.

Heagerty, A.H.M., Smith, A., English, J., Lear, J., Perkins, W., Bowers, B., Jones, P., Gilford, J., Alldersea, J., Fryer, A.A. and Strange, R.C. (1996). Susceptibility to multiple cutaneous basal cell carcinomas: significant interactions between glutathione S-transferase GSTM1 genotypes skin type and male gender. Br. J. Cancer 73: 44-48.

Helzlsouer, K.J., Selmin, O., Huang, H.Y., Strickland, P.T., Hoffman, S., Alberg, A.J., Watson, M., Comstock, G.W. and Bell, D. (1998). Association between glutathione S-transferase M1, P1, and T1 genetic poly- 
morphisms and development of breast cancer. J. Natl. Cancer Inst. 90: 512-518.

Klautau-Guimarães, M.N. (1993). Estudo genético da glutationa S-transferase: Enzima do metabolismo dos xenobióticos. PhD thesis, Faculdade de Medicina de Ribeirão Preto, Universidade de São Paulo, São Paulo, SP, Brazil.

Krieger, H., Morton, N.E., Mi, M.P., Azevêdo, E., Freire-Maia, A. and Yasuda, N. (1965). Racial admixture in Northeastern Brasil. Ann. Hum. Genet. 19: 113-125.

Lahiri, D.K. and Nurnberger Jr., J.I. (1991). A rapid non-enzymatic method for the preparation of HMW DNA from blood for RFLP studies. Nucleic Acids Res. 19: 5444.

Laisney, V., Van Cong, N., Gross, M.S. and Frezal, J. (1984). Human genes for glutathione S-transferases. Hum. Genet. 68: 221-227.

Lin, J.L., Han, C.Y., Bernstein, D.A., Hsiao, W., Lin, B.K. and Hardy, S. (1994). Ethnic distribution of the glutathine transferase Mu 1-1 (GSTM1) null genotype in 1473 individuals and application to bladder cancer susceptibility. Carcinogenesis 15: 1077-1081.

Lopez-Camelo, J.S., Cabello, P.H. and Dutra, M.G. (1996). A simple model for the estimation of congenital malformation frequency in racially mixed populations. Braz. J. Genet. 19: 659-663.

Mannervick, B. (1985). The isoenzymes of glutathione transferase. Adv. Enzymol. 57: 357-417.

Mikelsaar, A.V., Tasa, G., Pärlist, P. and Uusküla, M. (1994). Human glutathione S-transferase GSTM1 genetic polymorphism in Estonia. Hum. Hered. 44: 248-251.

Mukanganyama, S., Masimirembwa, C.M., Naik, Y.S. and Hasler, J.A. (1997). Phenotyping of the glutathione S-transferase M1 polymorphism in Zimbabweans and the effects of chloroquine on blood glutathione S-transferases M1 and A. Clin. Chim. Acta 265: 145-155.

Pessah-Rasmussen, H., Stavenow, L., Seidegard, J. and Berglund, A. (1992). Human fibroblasts lacking trans-stilbene oxide active glutathione ex- hibit increased cell death when exposed to polycyclic aromatic hydrocarbons. Pharm. Toxicol. 70: 361-365.

Saiki, R.K., Gelfand, S., Stoffel, S., Scharf, S.J., Higuchi, R., Horn, G.T., Mullis, K.B. and Erlich, H.A. (1988). Primer-directed enzymatic amplification of DNA with a thermostable DNA polymerase. Science 239: 487-491.

Seidegard, J., Pero, R.W., Miller, D.G. and Beattie, E.J. (1986). A glutathione transferase in human leukocytes as a marker for the susceptibility to lung cancer. Carcinogenesis 7: 751-753.

Seidegard, J., Yorachek, W.R., Pero, R.W. and Pearson, W.R. (1988). Hereditary differences in the expression of the human glutathione transferase active on trans-stilbene oxide are due to a gene deletion. Proc. Natl. Acad. Sci. USA 85: 7293-7297.

Strange, R.C. (1993). The glutatione S-transferase GSTM1 locus and cancer susceptibility. In: Structure and Function of Glutathione Transferases (Tew, K., Mannervick, B., Mantle, T.J., Pickett, C.B. and Hayes, J.D., eds.). CRC Press, Boca Raton, Florida, pp. 160-171.

Strange, R.C., Matharoo, B., Faulder, C.G., Jones, P., Cotton, W., Elder, J.B. and Deakin, M. (1991). The human glutathione S-transferase: a case-control study of the incidence of the GST1 0 phenotype in patients with adenocarcinoma. Carcinogenesis 12: 25-28.

Widersten, M., Pearson, W.R., Engström, A. and Mannervik, B. (1991). Heterologous expression of the allelic variant $\mu$-class glutathione transferases $\mu$ and $\psi$. Biochem. J. 276: 519-524.

Wolkoff, A.W. (1980). The glutathione S-transferases: their role in the transport of organic anions from blood to bile. Int. Ver. Physiol. 21: 151-169.

Zhao, L., Alldersea, J., Fryer, A., Tighe, A., Ollier, B., Thomson, W., Jones, P. and Strange, R. (1994). Polymorphism at the glutathione S-transferase GSTM1 locus: a study of the frequencies of the GSTM1 A, B, A/B and null phenotypes in Nigerians. Clin. Chim. Acta 225: 85-88.

(Received December 9, 1999) 
